\title{
Effectiveness of Modular Training at Farmers' Training Center: Evidence from Fogera District, South Gondar Zone, Ethiopia
}

\author{
Wuletaw Mekuria* \\ Addis Ababa University College of Development Studies Center for Rural Development, Addis Ababa, Ethiopia \\ *Corresponding author: wuletaw.m@gmail.com
}

Received May 26, 2014; Revised June 11, 2014; Accepted August 05, 2014

\begin{abstract}
Training helps to enhance human capabilities in improving the level of thinking and ways of life. However, in rural Ethiopia, access to modular training is not well deliberated. This paper is attempted to understand effectiveness of modular training at farmers' training centre in Fogera district. The aim of the research was identifying the knowledge gap of the farmers, linkages of institutions and positive deviances of training centres. The study was conducted in 2010 from 120 households selected in systematic random sampling. Interview schedule was applied for data collection supplemented with field observation and focused group discussion. Teacher made test, practice test, Likert scale and linkage matrix were employed to examine the effectiveness of modular training. The result revealed that knowledge, skill, attitude and institutional linkage are essential variables which influence effectiveness of modular training significantly. This study has also shown that trained farmers are likely to be positive deviants in beekeeping than untrained farmers. Even though the duration and seasons of training were adequate and convenient, low participation of women and theoretical nature of trainings made the program ineffective. This implies that practical training and integration of actors enable to diversify production potentials. Emphasis should be given for proper functioning of training centres that could be achieved through stability of the program, institutional linkage and knowledge management schemes.
\end{abstract}

Keywords: modular training, positive deviance, knowledge, institutional linkage

Cite This Article: Wuletaw Mekuria, "Effectiveness of Modular Training at Farmers' Training Center: Evidence from Fogera District, South Gondar Zone, Ethiopia." American Journal of Rural Development, vol. 2, no. 3 (2014): 46-52. doi: 10.12691/ajrd-2-3-2.

\section{Introduction}

Ethiopian development policy and strategy document had given credence to different arrangements including capacity building program to strengthen local institutions and organizations so as to reduce the bottleneck of development. Twenty five Technical Vocational and Education Training Colleges had been established at the beginning of 2000 with the main objective of creating and developing human resource and institutional capacity that would have been beneficial impacts on medium and long term objectives of the country (Habtemariam, 2007).

Adult literacy rate of Ethiopian population who can read and write and Human Development Index were $36.3 \%$ and 0.406 respectively. Farmers are more likely to adopt innovations and become more productive with the help of basic education and extension services. In rural areas, especially poor farmers, access to education is still much lower and the quality of non-formal education is poorer and often irrelevant to their lives. Several trainings, especially modular and other non modular trainings have been given to farmers in rural communities. Currently, Ethiopian government has been launched strategies and implementing directions to initiate modular training at farmer training centers level as a means to meet the required level of knowledge. Hence, modular training is the main option within which the solution is found. For the main purpose of modular training many farmer training centers have been established since 2004 in Ethiopia (Kristin et al., 2009).

Delivery of effective modular trainings can be successful once linkage of different organizations and stakeholders realized at different level of institutions. In recent years, more attention has been given to use newly established farmer training centers where modular trainings can be delivered for youth farmers to increase production and productivity by enabling them more skillful and knowledgeable producers. It could also take an additional responsibility undertaking farmer based research in the area of agricultural interventions. The research and extension department was charged with the responsibility to support those needs through effective farmers' training (Tsion, 2008).

Although government and NGOs made restless efforts to improve the living standard of farmers, there were major confronts on the effectiveness of modular trainings including cross cutting issues such as gender, home science, communication skills, marketing, post harvest 
technologies were not incorporated. There was lack of facilities and inappropriate time of training (Kristin et al., 2009). In addition, lack of demonstration areas, tasks and duties of modules were not easily understandable for development agents and farmers, lack of training aids, less involvement of female farmers and low follow up of training programs were some of the major constraints (Berhanu, 2006; Tsion, 2008).

Assessments of modular training were conducted elsewhere in the country and it was indicated that there were problems due to less functioning of those centers (Anteneh, 2008; MoE, 2008; Fisseha, 2009). This study was therefore focused on analyzing whether the training address the knowledge gap of the farmers and requirements effectively and enabled them to use the acquired knowledge, identifying linkages of farmer training centers among and between public and private institutions and identifying of positive deviances in their performance and contributions for rural communities.

\section{Methods and Data}

\subsection{Sample Size and Methods of Sampling}

The research design was non-experimental type based on a multi-stage sampling procedure. In the first stage, among 25 peasant associations (PAs) of the district, four of them were selected purposively, based on the nature of the study which was identified, in consultation of Fogera Office of Agriculture and Rural Development. The rationale of taking four PAs purposively as the unit of analysis was; potential marketable and promising commodities including beekeeping, fattening of small ruminants and dairy commodities were selected for the purpose of study on which modular trainings were delivered. In the second stage, household heads in the selected PAs were listed down as trained and untrained farmers separately. Finally, 60 trained and 60 untrained farmers, a total of 120 respondent farmers were selected randomly.

\subsection{Data Sources and Methods of Data Collection}

Both qualitative and quantitative data types were collected from primary and secondary sources. Secondary data were collected from various sources and from Office of Agriculture and Rural Development of the district.
Primary data were collected from the sampled respondents. The interview schedule was pre-tested prior to the actual survey and essential amendments were made. Structured interview was conducted with the help of enumerators after training, five focused group discussions, fifteen key informants were also interviewed, and direct observation using checklists have been applied. Secondary data were gathered from different articles, proceedings, government documents and other secondary data sources.

\subsection{Methods of Data Analysis}

Descriptive statistics and inferential tests, with careful in-depth analysis, were made. The knowledge aspect of farmers was analyzed using Teacher-Made-Test. In connection with knowledge, skill and attitude of farmers were analyzed with practice test and Liker scale respectively related to three commodities namely beekeeping, dairy and fattening. Moreover, an institutional linkage was examined looking in to linkage matrix and actor linkage map.

\section{Results and Discussion}

The selection criteria of farmers for modular training were: Innovativeness, creativity, interest, voluntariness, school dropouts, agricultural engagement, model and exemplary farmers, age of 18 and above, both male and female farmers, grade four and above, and ability of sharing knowledge to their colleagues (Adebabay et al., 2008). As a matter-of-fact, the selections made so far showed that both male and female farmers had not participated in equally in modular trainings. The criteria of educational status were violated in selection processes because non-educated farmers were involved and trained in modular trainings.

Only 2.1\% ( $\mathrm{N}=2)$ and $5.7 \%(\mathrm{~N}=34)$ were trained and untrained females respectively that participated in beekeeping, dairy and fattening commodities. From the total of 120 respondent farmers only $1.7 \%(\mathrm{~N}=1)$ and $6.7 \%(\mathrm{~N}=4)$ trained and untrained females were interviewed respectively. The result showed that about $32 \%$ farmers had low educational level. As the explanation of district experts, most of selected farmers were presumed to be progressive farmers or team leaders of development activities. This finding was agreed with the findings of Kefyalew (2006) and Tsion (2008).

Table 1. Profiles of respondents

\begin{tabular}{|c|c|c|c|c|c|c|c|c|}
\hline \multirow{2}{*}{ No } & \multirow{2}{*}{ Characteristics } & \multirow{2}{*}{ Category } & \multicolumn{2}{|c|}{ Trained } & \multicolumn{2}{|c|}{ Untrained } & \multicolumn{2}{|c|}{ Total } \\
\hline & & & $\mathrm{F}$ & $\%$ & $\mathrm{~F}$ & $\%$ & $\mathrm{~F}$ & $\%$ \\
\hline \multirow[t]{3}{*}{1} & Sex & & & & & & & \\
\hline & & Male & 59 & 98.3 & 56 & 93.3 & 115 & 95.8 \\
\hline & & Female & 1 & 1.7 & 4 & 6.7 & 5 & 4.2 \\
\hline \multirow[t]{6}{*}{2} & Educational status & & & & & & & \\
\hline & & No education & 3 & 5.0 & 15 & 25.0 & 18 & 15.0 \\
\hline & & Read and write & 16 & 26.7 & 21 & 35.0 & 37 & 30.8 \\
\hline & & Grade 1-4 & 12 & 20.0 & 13 & 21.7 & 25 & 20.9 \\
\hline & & Grade 5-8 & 22 & 36.7 & 9 & 15.0 & 31 & 25.8 \\
\hline & & Above grade 8 & 7 & 11.6 & 2 & 3.3 & 9 & 7.5 \\
\hline
\end{tabular}

Source: Own survey, 2010

The slack periods of production system in Fogera are around October and February. Length and styles of the trainings were done in line with the interest of majority of the farmers. Here the most challenging issues were training methods and the proportions of methodology of the training. The syllabus has been designed to be $80 \%$ practical and 20\% theory (Adebaby et al., 2007). Training sessions were conducted for different durations as short as 30 days to 90 days. For instance, Alember was conducted training from April to June, Woji was conducted for one 
month of training in February, Woreta. Zuria was delivered from April to May and Shina was trained in April. Most of the trainings were delivered two days per week and for 2 to 4 hrs daily. This training duration was designed by development agents and Office of Agriculture and Rural Development of the district considering cropping seasons and other technical and agro- ecological situations.

Table 2. Training delivery dimensions

\begin{tabular}{ccc}
\multicolumn{3}{c}{ Table 2. Training delivery dimensions } \\
\cline { 2 - 3 } Items & Trained farmers (N=60) \\
\cline { 2 - 3 } & Frequency & Percent \\
\hline Length of trainings & 50 & 83.3 \\
Sufficient & 10 & 16.7 \\
Not sufficient & & \\
Preferred style of & 53 & 88.3 \\
training & 7 & 11.7 \\
With interval & & \\
Continuous & 54 & 90.0 \\
Training mix & 3 & 5.0 \\
More theoretical & 3 & 5.0 \\
More practical & & \\
Balanced & 46 & 76.6 \\
Training methods & 9 & 15.0 \\
Class lecture & 3 & 5.0 \\
Mixed type & 1 & 1.7 \\
Group discussion & 1 & 1.7 \\
Demonstration & &
\end{tabular}

Source: Own survey data, 2010

Based on the data gathered from interview schedules, $91.7 \%$ respondents explained that the training content was relevant in terms of the training contents towards farming communities; whereas $8.3 \%$ respondents explained that the training content was not relevant, but it doesn't mean that only training contents can achieve the stated objectives for successful training results. Duration, proportion, seasons, techniques and styles of the training were very important methodological aspects that could affect the effectiveness of modular training.

Poor time management, more lecture types of training, low participatory method of training, poorly organized delivery of the training without lesson plan were the major limitations of the program. Trainees also were not participated in full commitment and interest; rather they were recruited as if some benefit or incentive is being paid by the trainers. Alember and Woji centers used somehow practical trainings such as framed, transitional and traditional beehives to compare and contrast traditional with modern techniques of practice and its application in terms of production and productivity. They had been taking practical training on bee splitting, transferring, wax making, honey harvesting techniques and some other important tasks to increase the productivity of honey. The remaining two PAs (Woreta Zuria and Shina) were selected and trained on dairy and sheep fattening practices.

There was no follow up, feedback and continuous assessment at the time of training. Moreover, researcher's observation also indicated that there was difficulty in getting organized, disaggregated, reliable, timely and accurate data on related issues of modular training due to many reasons such as turnover of development agents, low level of data compiling techniques, low management skills, lack of stationeries and lack of commitment at all levels.

\subsection{Knowledge}

A 'Teacher-made-test' was administered on apiculture, dairy and fattening and independent sample t-test was applied to compare the mean difference of trained and untrained farmers to look at their knowledge gaps.

Table 3. Knowledge test of sample households

\begin{tabular}{|c|c|c|c|c|c|}
\hline Respondents & $\mathrm{N}$ & Mean & SD & t- value & p-value \\
\hline Trained & 60 & 17.38 & 3.11 & $2.952 * * *$ & 0.004 \\
\hline Untrained & 60 & 15.82 & 2.69 & & \\
\hline
\end{tabular}

The t-test showed that there was high significant $(\mathrm{p}<0$. 01) difference between mean scores of trained and untrained farmers (probability $p=0.004$ ). Knowledge test indicates that the trained farmers had better level of knowledge than untrained farmers.

From the result obtained, it could be justified as, modular training kept the farmers more knowledgeable in promoting those commodities, especially with reference to beekeeping and dairy. The result of the study was in line with the findings of Babur (2009), who reported that knowledge of coffee management practices of members of Farmer Field School was higher than the non members. Although the training content is different, these findings agreed with the findings of Kefyalew (2006) and Tsion (2008) that trainings kept the trained farmers more informed and acquired knowledge.

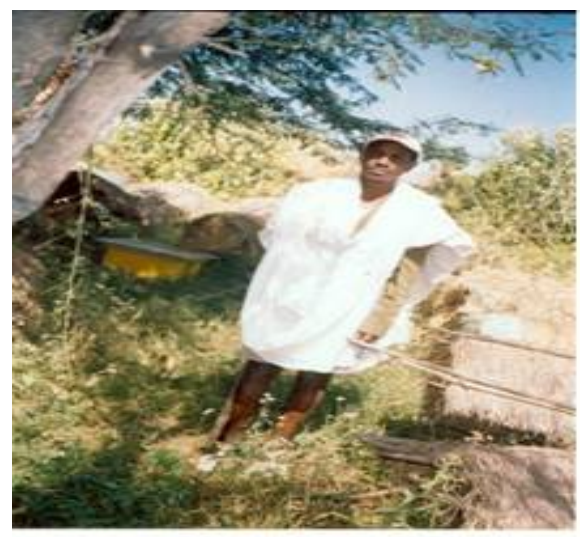

\section{Case Study}

Fiseha Binega (Trained farmer) in Alember, Fogera district

This case study was focused on the knowledge gained from modular training in beekeeping practices. The effectiveness of modular training in promoting apiculture practices was best illustrated by one of trained farmer who lives in Alember peasant association, Fogera district. Fiseha Binega was a beekeeper aged 35 years and married who stated about the effectiveness of modular training in beehives management and other related beekeeping practices.

He said, "Five years back, I was selected as one of the training participants in beehive management in the village. Beekeeping is challenging, but it is an interesting enterprise because it needs serious follow-up, skill of management and experience. I have actively participated in farmers' training through group discussion; practical demonstration and group exercise because more than 15 beehives are belonging to me. Through group learning with the help of the facilitator (Amare Genetu), I have already acquired knowledge about the bee splitting, honey harvesting systems, transitional beehives making, dearth period management, housing, transferring of bees, wax 
making, and other bee-enemies management practices. In this aspect, traditional bee hives were not able to give honey more than $5 \mathrm{~kg}$ per hive per year. Currently, honey production has been raised to $25 \mathrm{~kg}$ per improved hive per year. This change would never have happened, if I would not have participated in modular training. I have performed practically what I have learned in the Farmers' Training Center."

He explained further as "Now-a-days, I use improved traditional, transitional and framed beehives. In the near future, I want to increase the number of beehives with proper management practices. As you see, in addition to appropriate management, there is a big natural forest "Alemsaga" in close proximity to my home that gives additional potential for honey production. In general, this is the outcome of training from which knowledge and better practices were acquired."

\subsection{Practice}

Practice test was administered on trained and untrained farmers for apiculture, dairy and fattening. The mean difference of practices of trained and untrained farmers was analyzed using independent sample t-test and results were presented below in Table 5 .

Table 4. Practice difference of sample households

\begin{tabular}{|c|c|c|c|c|c|}
\hline Respondents & $\mathrm{N}$ & Mean & SD & t-value & p-value \\
\hline Trained & 60 & 4.45 & 1.53 & $1.981^{* *}$ & 0.05 \\
\hline Untrained & 60 & 3.82 & 1.94 & & \\
\hline
\end{tabular}

The mean scores of practices of trained respondents were significantly higher than that of untrained respondents. This may be due to the fact that trained farmers might have acquired farming practices of beekeeping, dairy and fattening with 'learning by doing' and the trainings offered by farmer training centers have been improved the level of application of the scientific recommendations. Trained farmers had frequent contacts with facilitators during the training periods that result in to higher knowledge in promoting diverse commodities practices in their locality. Babur (2009) also stated that the management practices of coffee by farmer field school member farmers were significantly higher than those of non-FFS member farmers.

\subsection{Attitude}

Based on the Likert scale measurement, the mean scores of trained and untrained farmers' attitude were analyzed using independent sample t-test.

Table 5. Attitude difference of sample respondents

\begin{tabular}{|c|c|c|c|c|c|}
\hline Respondents & $\mathrm{N}$ & Mean & SD & t-value & p-value \\
\hline Trained & 60 & 23.30 & 2.417 & $3.621^{* * *}$ & 0.000 \\
\hline Untrained & 60 & 21.71 & 2.373 & & \\
\hline
\end{tabular}

The mean score of attitude of trained farmers was significant at $1 \%(\mathrm{p}<0.01)$ of improvement due to the training in Farmers' Training Center on agricultural practices, especially with reference to the beekeeping, dairy and fattening of small ruminants. This showed that trained farmers had more favorable attitude towards those market- oriented commodities as compared to untrained farmers. This was in line with the findings of Kefyalew (2006), Tsion (2008) and Babur (2009), who stated that training by formal and informal institutions such as community skill training centers, research centers, farmer field schools, and exposing ones to scientific information help individuals to think rationally and logically in all aspects of the life.

\subsection{Actor Linkage Map}

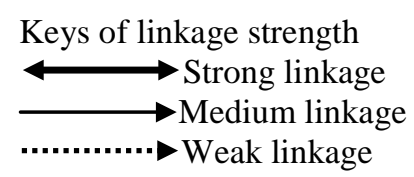

Key actors were categorized in to public, private sectors and NGOs. Thus, a total of 12 actors were identified involved in modular training at Farmer Training Center in study area. Actor linkage map was created by placing the Farmer Training Centre (FTC) at the center and connecting other actors based on their contribution to the system. Prime movers were internal and external actors who took decisions that were most important to the system. These prime movers in the diagram were also called "drivers of the change". The map showed intensities of each actor's linkage. Hence, farmers, Development agents (DAs), Woreda Office of Agriculture and Rural Development (WoARD), cooperatives, Amhara Credit and Saving Institutions (ACSI) and Improving Productivity Market Success (IPMS) project were identified as primary actors. Administrators, Department of Agriculture and Rural Development (DoARD), Bureau of Agriculture and Rural Development (BoARD) and Ministry of Agriculture and Rural Development (MoARD) were identified in a medium category, and Agricultural, Technical, Vocational, Education and Training (ATVETs) and primary schools were classified as tertiary level actors.

DAs, WoARD, farmers, cooperatives, and ACSI had strong linkage with FTCs. The probable reason for strong and two way linkages might be those institutions were exist in the locality so that information sharing and daily communication was possible. IPMS project had strong but unidirectional linkage with FTCs and this project supports only four FTCs in the Woreda. Actors such as DoARD, BoARD and MoARD had medium and unidirectional linkages. These actors had their own roles for FTCs, but they didn't get direct services and benefits from FTCs whereas "Administration" had medium and mutual linkages and obtained services from FTCs. Two actors (schools and Woreta ATVET College) were identified as weak actors and have unidirectional linkage and their roles were insignificant based on its relationship.

\subsection{Actor Linkage Matrix}

Actor linkage matrix format was more useful than actor linkage map. The advantage of using this format was not only for clarification of existence and type of linkage but also it tells the frequency and intensity of contact among actors themselves. Thus a total of 13 actors had been identified with respondents and key informants who have been involved in training process and establishment of FTCs. From the Table below, 'Nil' indicates there was no institutional linkage between actors. In addition to the prescience of linkages between institutions, their strength (1. Indicates strong linkage 2. Describes medium linkage 3. Shows weak linkage) was also explained using numbers.

Linkage matrix described with various activities such as training, material provision, module preparation and 
distribution, funding, input and credit supply, technical advice, communication, information sharing, management,

supervision, apprenticeship programs and other similar activities.

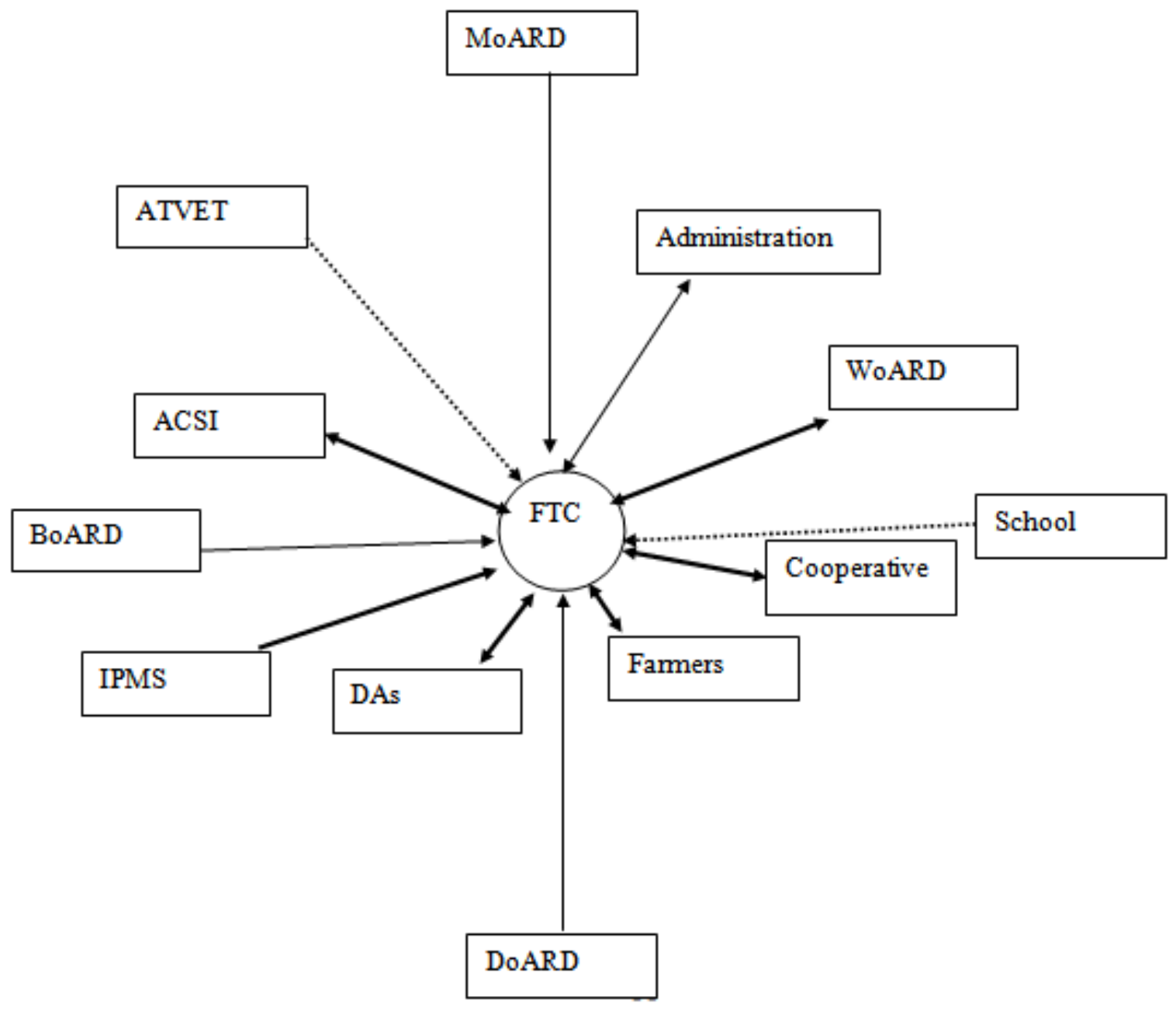

Figure 1. Actor linkage map Source: Own qualitative data (2010)

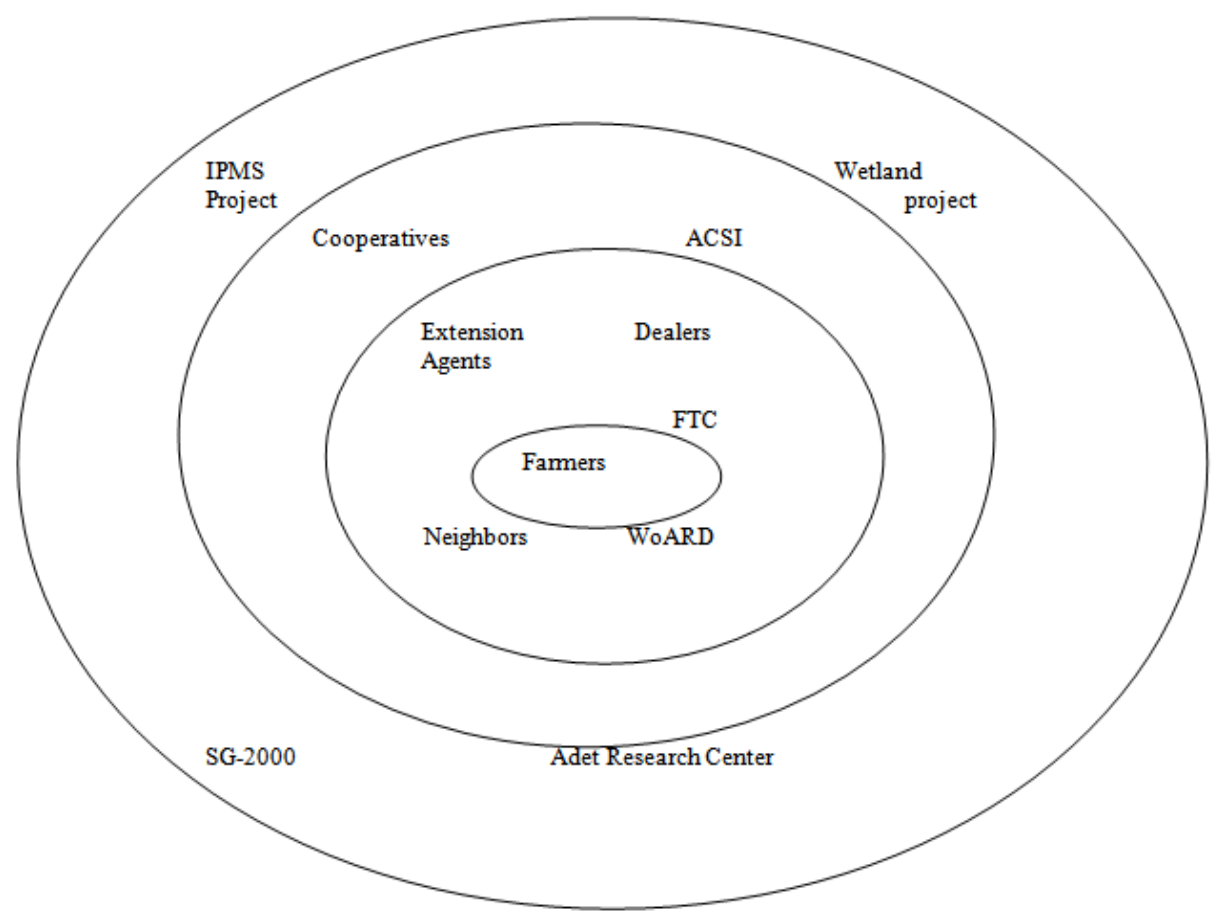

Figure 2. Knowledge flow among actors Source: Own presentation 
Table 6. Linkage matrix of development actors

\begin{tabular}{|c|c|c|c|c|c|c|c|c|c|c|c|c|c|}
\hline & $\begin{array}{c}\text { FT } \\
\text { C }\end{array}$ & $\begin{array}{l}\text { Farme } \\
\text { rs }\end{array}$ & DAs & WoARD & $\begin{array}{l}\text { DoAR } \\
\text { D }\end{array}$ & $\begin{array}{l}\text { BoAR } \\
\text { D }\end{array}$ & MoARD & ATVET & ACSI & $\begin{array}{c}\text { Cooperat } \\
\text { ives }\end{array}$ & School & IPMS & $\begin{array}{c}\text { Administr } \\
\text { ators }\end{array}$ \\
\hline FTC & & $\begin{array}{l}\text { Traini } \\
\text { ng, } \\
\text { extens } \\
\text { ion } \\
\text { servic } \\
\text { e (1) }\end{array}$ & $\begin{array}{l}\text { Traini } \\
\text { ng. } \\
\text { office } \\
\text { servic } \\
\text { e (1) }\end{array}$ & $\begin{array}{c}\text { Area of } \\
\text { Technol } \\
\text { ogy } \\
\text { Adoptio } \\
\text { n(1) }\end{array}$ & $\begin{array}{l}\text { Teachi } \\
\text { ng aids } \\
\text { and } \\
\text { Suppo } \\
\text { rt (2) }\end{array}$ & $\begin{array}{l}\text { Modul } \\
\text { e and } \\
\text { text } \\
\text { Suppo } \\
\text { rt (2) }\end{array}$ & $\begin{array}{l}\text { Guidelin } \\
\text { e } \\
\text { preparati } \\
\text { on (2) }\end{array}$ & $\begin{array}{l}\text { Supply of } \\
\text { Das (3) }\end{array}$ & $\begin{array}{c}\text { Source } \\
\text { of data } \\
\text { (1) }\end{array}$ & $\begin{array}{c}\text { Source } \\
\text { of data } \\
\text { (1) }\end{array}$ & $\begin{array}{l}\text { Teachi } \\
\text { ng aids } \\
\text { (3) }\end{array}$ & $\begin{array}{l}\text { Trainin } \\
\text { g and } \\
\text { technica } \\
\text { l } \\
\text { support } \\
\text { (1) }\end{array}$ & $\begin{array}{l}\text { Center and } \\
\text { source of } \\
\text { informatio } \\
n \text { for } \\
\text { administra } \\
\text { tion (2) }\end{array}$ \\
\hline Farmer & & & $\begin{array}{c}\text { Traini } \\
\text { ng } \\
(1)\end{array}$ & $\begin{array}{c}\text { Material } \\
\text { provisio } \\
\text { n (1) }\end{array}$ & $\begin{array}{c}\text { Techni } \\
\text { cal } \\
\text { suppor } \\
\text { t } \\
(2) \\
\end{array}$ & $\begin{array}{l}\text { Modul } \\
\text { e } \\
\text { provisi } \\
\text { on (3) }\end{array}$ & Nil & $\begin{array}{l}\text { Problem } \\
\text { identificati } \\
\text { on (3) }\end{array}$ & $\begin{array}{c}\text { Financi } \\
\text { ng } \\
\text { Credit } \\
(1)\end{array}$ & $\begin{array}{c}\text { Input } \\
\text { supply } \\
\text { Marketin } \\
\text { g (1) }\end{array}$ & $\begin{array}{l}\text { Educat } \\
\text { ion (3) }\end{array}$ & $\begin{array}{l}\text { Technic } \\
\text { al } \\
\text { support } \\
\text { (1) }\end{array}$ & $\begin{array}{l}\text { Administr } \\
\text { ation } \\
\text { (2) }\end{array}$ \\
\hline DAs & & & & $\begin{array}{l}\text { Technic } \\
\text { al } \\
\text { support } \\
\text { (1) }\end{array}$ & $\begin{array}{l}\text { Techni } \\
\text { cal } \\
\text { suppor } \\
\text { t (3) }\end{array}$ & $\begin{array}{l}\text { Traini } \\
\text { ng (3) }\end{array}$ & $\begin{array}{l}\text { Policy } \\
\text { and } \\
\text { Strategy } \\
\text { (3) }\end{array}$ & $\begin{array}{l}\text { Training, } \\
\text { knowledge } \\
\text { sharing (1) }\end{array}$ & $\begin{array}{l}\text { Organiz } \\
\text { ing } \\
\text { farmers } \\
\text { (3) }\end{array}$ & $\begin{array}{c}\text { Source } \\
\text { of data, } \\
\text { organizin } \\
\text { g farmers } \\
\text { (3) }\end{array}$ & $\begin{array}{l}\text { Materi } \\
\text { al } \\
\text { support } \\
\text { (3) }\end{array}$ & $\begin{array}{l}\text { Experie } \\
\text { nce } \\
\text { share } \\
(1)\end{array}$ & $\begin{array}{c}\text { Farmers' } \\
\text { selection(1 } \\
\text { ) }\end{array}$ \\
\hline WoARD & & & & & $\begin{array}{l}\text { Techni } \\
\text { cal } \\
\text { suppor } \\
\mathrm{t}(1)\end{array}$ & $\begin{array}{l}\text { Modul } \\
\mathrm{e} \\
\text { provisi } \\
\text { on (2) }\end{array}$ & $\begin{array}{c}\text { Module } \\
\text { provisio } \\
\mathrm{n}(3)\end{array}$ & $\begin{array}{l}\text { Apprentic } \\
\text { eship } \\
\text { (3) }\end{array}$ & $\begin{array}{c}\text { Credit } \\
\text { facilitat } \\
\text { ion } \\
(1)\end{array}$ & $\begin{array}{c}\text { Input } \\
\text { facilitatio } \\
\text { n } \\
(1)\end{array}$ & Nil & $\begin{array}{l}\text { Funding } \\
\text { and } \\
\text { material } \\
(1)\end{array}$ & $\begin{array}{c}\text { Informatio } \\
\text { n sharing } \\
\text { (1) }\end{array}$ \\
\hline DoARD & & & & & & $\begin{array}{l}\text { Techni } \\
\text { cal } \\
\text { suppor } \\
\text { t (1) }\end{array}$ & $\begin{array}{c}\text { Technic } \\
\text { al } \\
\text { cooperat } \\
\text { ion } \\
(3) \\
\end{array}$ & $\begin{array}{c}\text { Supervisio } \\
\mathrm{n} \\
\text { (3) }\end{array}$ & $\begin{array}{l}\text { Credit } \\
\text { facilitat } \\
\text { ion (3) }\end{array}$ & $\begin{array}{c}\text { Input } \\
\text { facilitatio } \\
\text { n } \\
\text { (3) }\end{array}$ & Nil & $\begin{array}{l}\text { Material } \\
\text { support } \\
\text { (1) }\end{array}$ & $\begin{array}{c}\text { Informatio } \\
\mathrm{n} \\
(2)\end{array}$ \\
\hline BoARD & & & & & & & $\begin{array}{c}\text { Module } \\
\text { Provisio } \\
\text { n (1) }\end{array}$ & $\begin{array}{l}\text { Training } \\
\text { of DAS } \\
\text { (1) }\end{array}$ & $\begin{array}{c}\text { Loan } \\
\text { facilitat } \\
\text { ion } \\
\text { (3) }\end{array}$ & $\begin{array}{l}\text { Input } \\
\text { supply } \\
(3)\end{array}$ & Nil & $\begin{array}{l}\text { Funding } \\
\text { activitie } \\
\text { s (1) }\end{array}$ & $\begin{array}{c}\text { Informatio } \\
n \\
(3)\end{array}$ \\
\hline MoARD & & & & & & & & Nil & Nil & Nil & Nil & $\begin{array}{l}\text { Technic } \\
\text { al } \\
\text { coopera } \\
\text { tion (1) }\end{array}$ & Nil \\
\hline ATVET & & & & & & & & & Nil & Nil & Nil & Nil & Nil \\
\hline ACSI & & & & & & & & & & $\begin{array}{l}\text { Informati } \\
\text { on } \\
\text { sharing } \\
\text { (3) }\end{array}$ & Nil & Nil & $\begin{array}{c}\text { Credit } \\
\text { facilitation } \\
\text { (1) }\end{array}$ \\
\hline Co-ops & & & & & & & & & & & Nil & Nil & $\begin{array}{c}\text { Input } \\
\text { facilitation } \\
\text { (1) }\end{array}$ \\
\hline School & & & & & & & & & & & & Nil & $\begin{array}{c}\text { Education } \\
\text { matters (1) }\end{array}$ \\
\hline IPMS & & & & & & & & & & & & & $\begin{array}{l}\text { Capacity } \\
\text { building } \\
\text { (2) }\end{array}$ \\
\hline $\begin{array}{l}\text { Administr } \\
\text { ators }\end{array}$ & & & & & & & & & & & & & \\
\hline
\end{tabular}

\subsection{Knowledge and Information Sharing}

Frequency of contact and sources of information on Figure 2, farmers were the center of knowledge flow diagram. Information and knowledge sharing were involved in trainings. Information that accessed by farmers was from trainings, advice, technical support, experience share, market prices, inputs and consultancy services.

The primary sources of knowledge and information sharing were Extension Agents, market dealers, neighbors, FTCs and WoARD. Farmers had accessed in daily, weekly or monthly basis for information from different actors for their own purposes. The probable reason might be those actors living with farmers had more close contact than other development partners.

ACSI, administrators, and cooperatives were secondary sources of information for farmers that had less frequency of contact with farmers followed by projects, NGOs and research institutions. It indicates that the possibility of getting knowledge by farmers from NGOs and projects was very low. Hence, this explanation has the same opinion with the findings of Deribe (2007) who stated as "neighbors, DAs, relatives and religious organizations were the major and most important sources of information for farmers.”

\subsection{Positive Deviance}

Two FTCs (Alember and Woji) were established with participation of farmers. Even though, the training was conducted in Shina and Woreta Zuria, FTCs were not constructed based on the requirements of the design of FTCs.

Table 7. Farmers' participation in functioning of FTCs

\begin{tabular}{|c|c|c|c|c|c|c|c|}
\hline \multirow{2}{*}{$\begin{array}{c}\text { Participation in } \\
\text { FTC } \\
\text { functioning }\end{array}$} & \multicolumn{2}{|c|}{$\begin{array}{l}\text { Trained } \\
\text { farmers } \\
(\mathrm{N}=60)\end{array}$} & \multicolumn{2}{|c|}{$\begin{array}{l}\text { Untrained } \\
\text { farmers } \\
(\mathrm{N}=60)\end{array}$} & \multicolumn{2}{|c|}{$\begin{array}{c}\text { Total } \\
(\mathrm{N}=60)\end{array}$} & \multirow[t]{2}{*}{$\begin{array}{l}\text { Chi- } \\
\text { square } \\
\left(X^{2}\right)\end{array}$} \\
\hline & $\mathrm{F}$ & $\%$ & $\mathrm{~F}$ & $\%$ & $\mathrm{~F}$ & $\%$ & \\
\hline Participated & 37 & 61.7 & 4 & 6.7 & 41 & 34.2 & $40.346 * * *$ \\
\hline $\begin{array}{c}\text { Not participated } \\
\text { Nature of } \\
\text { participation }\end{array}$ & 23 & 38.3 & 56 & 93.3 & 79 & 65.8 & $(p=0.000)$ \\
\hline $\begin{array}{l}\text { No } \\
\text { participation }\end{array}$ & 23 & 38.3 & 56 & 93.3 & 79 & 65.8 & 40.728 *** \\
\hline $\begin{array}{c}\text { FTC } \\
\text { construction }\end{array}$ & 29 & 48.3 & 3 & 5.0 & 32 & 26.7 & $(p=0.000)$ \\
\hline Committee & 1 & 1.7 & & & 1 & 0.8 & \\
\hline Mixed types & 7 & 11.7 & 1 & 1.7 & 8 & 6.7 & \\
\hline
\end{tabular}


Activities involved in establishment of FTCs were construction, committee mobilization, and other related actions. Participation was in terms of labor, fencing, land preparation, material provision and awareness creation. Most of activities were achieved through passive participation that means people had participated in by being told what was going to happen announced by administrators or development agents. Nevertheless, in this regard, participation of trained farmers was better than untrained farmers. The possible reason might be trained farmers had close relation to development agents and administrators, or might have access for information about the roles of FTCs due to most of trained farmers were involved in different committee activities that made them more committed towards the roles FTCs.

Conducting training, motivation, provision of local sitting materials, selection of trainees, knowledge and information flow, deliver extension services, socialization (arbitration, discussions, appointments, and the like), storage services for farm implements, served as office for development agents, trial and demonstration of improved practices and other related activities. Knowing positive deviant FTCs helped to take further actions and corrective measures in both sides of its strength and weakness.

Box 1. Alember Farmer Training Center

Alember is a small town located about $80 \mathrm{~km}$ far from Bahir Dar to North. The number of household head of Alember was about 1462 (1316 males and 146 females). At the time of survey, it was accessible to road, cooperative services, credit and saving institutions, private and public health clinics, market, public phone, both primary and junior schools, and was the center of supervision sites.

Modular training was delivered for 14 male and 2 female farmers in 2006 for consecutive three months (April to May). Training was conducted on apiculture. It was selected due to high potential of honey production in this area. The training was delivered on different tasks and duties of beekeeping such as bee splitting, transitional and improved traditional hives making, bee hunting, wax making and other honey production systems. Training methodology was more of practical. At the end of the course, trainees got certificates prepared by Woreda office of agriculture and rural development. Keeping other things similar, there were some deviations from other FTCs: two guards were recruited for the security of FTC, and their salary was being paid from the people's contribution.

More of practical aspect of training was conducted using trainees' resources at their village. Moreover, group discussions were made in

FTC. Most of (81\%) trained farmers were literate (grade four and above). In contrast, lack of water supply, fast turnover of DAs, lack of demonstration areas, non-functional management committee that formed at the time of FTC establishment are some of the deficiencies that would have been considered and reinforced by concerned bodies to take corrective measures. However, it didn't confirm the presence of deviations among those training centers.

Source: Key informant interviews, 2010

\section{Conclusion and Policy Recommendations}

Modular training is an existing intervention in Ethiopia designed for farming communities. The finding showed that trained farmers had better knowledge, skill and attitude than their counterparts. It implies that training is determinant construct for farmers in production processes. Less participation of female farmers in the training program, divergent institutional linkages and less effective training outputs are major policy implications that the government should give emphasis.

\section{Acknowledgement}

The author is grateful to IPMS project for its research grant. Special thanks also go to respondent farmers, enumerators and Mr. Tesfaye Alemu for their support at the time of data collection.

\section{References}

[1] Adebabay M. and Sajjaa, N., 2007. Farmers training center cooperation and management. Training guide in the context of SWHISA's pilot FTC operation in six Woredas. Second draft.

[2] Adebabay Mengist,Mesfin Astatkie, and Sajja, N., 2008. Assessments on DAs capability in planning and delivering of training to farmers in FTC setting.

[3] Anteneh Girma, 2008. Dairy services delivery in DebreZeit milk shed of Ada'a district. Analyzing options to develop pluralistic service delivery in the dairy sector. An MSc Thesis presented to School of Graduate Studies of Haramaya University, Ethiopia: pp. 55-56.

[4] Babur Damtie, 2009. Effectiveness of Framer Field School in promoting coffee management practices. The case of Jimma and Sidma Zone. An MSc Thesis presented to School of Graduate Studies of Haramaya University, Ethiopia: Pp75-83.

[5] Birhanu Gebremariam, 2006. Commercialization of Ethiopian agriculture. Extension service from input supplier to knowledge broker and facilitator.

[6] Deribe Kaske, 2007. Agricultural Net works of Farm Women and Roles of Agricultural Extension. The case of Dale Woreda, Southern Nation Nationalities and peoples' Region. An MSc. Thesis presented to School of Graduate Studies of Haramaya University, Ethiopia.49 p.

[7] Fisseha Teshome, 2009. Problems and Prospects of Farmers Training Centers. The case of Ada'a Woreda, East Shewa, Oromia Region. (Unpublished). An MSc Thesis presented to School of Graduate Studies of Haramaya University Ethiopia. 90p.

[8] Habtemariam Abate, 2007. Food and Agriculture Organization of the United Nations. Pp.10-19; 54-55. Review of Extension System Applied in Ethiopia with Special emphasis to the participatory Demonstration and Training Extension System, Addis Ababa. Ethiopia.

[9] Kefyalew Worku, 2006. Evaluation of Farmers Training Program: The Case of Eastern Harerghe (Babile and Hundenie).An MSc Thesis presented to School of Graduate Studies of Haramaya University, Ethiopia. 41p.

[10] Kristin, D., Burton S., David, A., 2009. International Food Policy Research Institute. Review of and Recommendations for Public Agricultural Extension in Ethiopia. P 18, 51.

[11] MoE (Ministry of Education), 2008. Review of the Ethiopian Education. Executive summary of training policy and implementation. Addis Ababa Ethiopia.

[12] Tsion Tesfaye, 2008. Effectiveness of training offered by an Ethiopian Institute of Agricultural Research to farmers. The case of Holeta, Melkasa, and Debre Zeit Agricultural Research centers. An MSc Thesis presented to the School of Graduate Studies of Haramaya University, Ethiopia. 58p. 